\title{
Heterologous MVA-S prime Ad5-S boost regimen induces high and persistent levels of neutralizing antibody response against SARS coronavirus
}

\author{
Lei Ba $\cdot$ Christopher E. Yi $\cdot$ Linqi Zhang $\cdot$ \\ David D. Ho • Zhiwei Chen
}

Received: 27 April 2007 /Revised: 30 May 2007 / Accepted: 1 June 2007 / Published online: 21 June 2007

(C) Springer-Verlag 2007

\begin{abstract}
Severe acute respiratory syndrome (SARS) is caused by a novel coronavirus (CoV), SARS-CoV. In previous studies, we showed that a SARS-CoV spike (S) glycoproteinbased modified vaccinia Ankara (MVA-S) vaccine could induce strong neutralizing antibody (Nab) response which might have played a critical role in protecting Chinese rhesus monkeys from the pathogenic viral challenge. To date, however, it remains unknown what the minimal level of $\mathrm{Nab}$ is required to achieve sterile immunity in humans. It is therefore important to explore techniques to maximize the level of Nab response in vivo. Here, we evaluate various vaccination regimens using combinations of DNA-S, MVA-S, and adenovirus type 5 (Ad5-S) vaccines. We show that in vaccinated mice and rabbits, a heterologous MVA-S prime with Ad5-S boost regimen induces the highest and most persistent level of $\mathrm{Nab}$ response when compared with other combinations. Interestingly, the initial level of $\mathrm{Nab}$ after prime does not necessarily predict the magnitude of the secondary response after the boost. Thus, our data provides a promising optimal regimen for vaccine development in humans against SARS-CoV infection.
\end{abstract}

Keywords SARS $\cdot$ SARS-CoV $\cdot$ MVA $\cdot$ Ad5 $\cdot$ Vaccine

\section{Introduction}

Shortly after the 2003 epidemic, the etiological agent for severe acute respiratory syndrome (SARS) was determined

L. Ba $\cdot$ C. E. Yi $\cdot$ L. Zhang $\cdot$ D. D. Ho $\cdot$ Z. Chen $(\bowtie)$

Aaron Diamond AIDS Research Center,

The Rockefeller University,

455 1st Avenue,

New York, NY 10016, USA

e-mail: zchen@adarc.org to be SARS coronavirus (SARS-CoV; Drosten et al. 2003; Ksiazek et al. 2003; Kuiken et al. 2003; Peiris et al. 2003). Similar to other viruses in the Coronaviridae family, SARS-CoV is characterized by its crown-like outer shell comprised primarily of spike (S) glycoproteins, which mediate viral entry by interacting with the host cellular ACE2 receptor (Li et al. 2003, 2005). We, along with other groups, previously showed that high titers of neutralizing antibodies (Nabs) are primarily directed toward the receptor-binding domain (RBD) of the S protein (Chen et al. 2005; He et al. 2005; Yi et al. 2005). Thus, the $\mathrm{S}$ protein and its RBD serve as a major viral target for vaccine design (Bukreyev et al. 2004; Chen et al. 2005; Yang et al. 2004).

Multiple forms of SARS vaccines including DNA-S, MVA-S, and Ad5-S have been independently proven to be effective in protecting animals from pathogenic SARS-CoV challenge (Bisht et al. 2004, 2005; Gao et al. 2003; Yang et al. 2004). The success of these studies has resulted in a minimal need for the development of a prime-boost regimen against SARS. To date, however, it remains unknown what the minimal level of Nabs is required to achieve sterile immunity in humans. There are recent evidences that a better protection may require sufficient amount of specific Nabs (Deming et al. 2006; Liu et al. 2007). It is therefore critical to explore techniques to maximize the level of $\mathrm{Nab}$ response in vivo. Here, we evaluate prime-boost strategies using various combinations of DNA-S, MVA-S, and Ad5-S to determine which regimen induces the highest and most persistent level of Nab response. We aim to identify an optimal vaccine regimen not only for preventing SARS-CoV infection but also for combating other tough viruses including the human immunodeficiency virus type one (HIV-1). 


\section{Materials and methods}

\section{DNA-S and MVA-S constructions}

The $\mathrm{S}$ gene was originally obtained from SARS-CoV HKU39849, an isolate from Hong Kong (GenBank accession number AY278491; Zeng et al. 2003). Based on the viral genome sequence, we constructed a codon-optimized fulllength $\mathrm{S}$ gene using synthetic overlapping oligonucleotides (Zhang et al. 2006). The optimized S gene was then cloned into a eukaryotic expression vector pcDNA3.1 under the control of a cytomegalovirus (CMV) promoter (pcDNA3.1OPT9; Invitrogen, Carlsbad, CA). The pcDNA3.1-OPT9 was used as the DNA-S vaccine. The construction of MVA-S has been previously described (Chen et al. 2005).

\section{Ad5-S construction}

The full-length, codon-optimized SARS $\mathrm{S}$ gene was inserted into a recombinant adenovirus-5 vector using $\mathrm{BD}$ Adeno-X Expression Systems 2 (BD Biosciences, Palo Alto, CA). Briefly, the full-length $\mathrm{S}$ gene from pcDNA3. 1-OPT9 was cloned into the pDNR-CMV donor vector and recombined with pLP-Adeno-X-CMV. Pac I-digested recombinant adenoviral vector was transfected into HEK-293 (ATCC, CRL-1573), and supernatant was collected 3-4 days posttransfection. This supernatant was used to infect a large culture of HEK-293 cells for large-scale production. Recombinant adenovirus (Ad5-S) was purified using two successive $\mathrm{CsCl}$ gradient (first: $d=1.25 \mathrm{~g} / \mathrm{ml}$ and $d=1.4 \mathrm{~g} / \mathrm{ml}$; second: $d=1.34 \mathrm{~g} / \mathrm{ml}$ ) centrifugation spins at $35,000 \mathrm{rpm}$ at $18^{\circ} \mathrm{C}$. Concentrated Ad5-S was dialyzed in phosphate buffered saline (PBS) and stored with glycerol at $-150^{\circ} \mathrm{C}$.

\section{Animal immunizations}

Six- to eight-week-old female BALB/c mice (Charles River Laboratories) were immunized by intramuscular (i.m.) injection of DNA-S, MVA-S, or Ad5-S. The dose of each vaccine was $200 \mu \mathrm{g}$ of DNA-S (in 200- $\mu$ l saline), $5 \times 10^{7} 50 \%$ tissue culture infective dose $\left(\mathrm{TCID}_{50}\right)$ of MVA-S or $5 \times 10^{7} \mathrm{TCID}_{50}$ of Ad5-S. We collected blood samples 2 weeks after the first immunization. Four weeks after the prime, we boosted several groups of primed mice (three mice per group) with DNA-S, MVA-S, or Ad5-S according to various regimens. The mice were killed, and their blood samples were used for analysis 2 weeks after the second immunization. New Zealand white rabbits (Charles River Laboratories) were immunized by i.m. injection of MVA-S or Ad5-S. Three rabbits were immunized with $5 \times 10^{8}$ TCID $_{50}$ of MVA-S, and another six were immunized with $5 \times 10^{8} \mathrm{TCID}_{50}$ of Ad5-S on day 0 . Four weeks later, Three MVA-S-primed animals were boosted with the same dose of Ad5-S, whereas the rest received MVA-S. Blood samples were collected 3 weeks after the first immunization and 2, 6, 9, and 16 weeks after the second immunization. All animal experiments were approved by and conducted in the Laboratory Animal Research Center at The Rockefeller University.

\section{Neutralization assay}

A pseudovirus-based neutralization assay was established to determine the humoral immune responses against SARS$\mathrm{CoV}$ (Chen et al. 2005). Briefly, the neutralizing activity of heat-inactivated sera $\left(56^{\circ} \mathrm{C}, 30 \mathrm{~min}\right)$ was determined by mixing $10 \mathrm{ng}$ of pseudovirus (in $30 \mu \mathrm{l}$ ) with diluted serum (in $30 \mu \mathrm{l}$ ) at $37^{\circ} \mathrm{C}$ for $1 \mathrm{~h}$. The SARS-pseudovirus was generated by cotransfecting $293 \mathrm{~T}$ cells with two plasmids pcDNA3.1-OPT9 and pNL4-3Luc ${ }^{+} \mathrm{Env}^{-} \mathrm{Vpr}^{-}$carrying the optimized S gene and a HIV-1 backbone, respectively. After neutralization, the mixture was combined with 16-ng polybrene (in 40- $\mu$ l medium) and added to HEK293TACE2 $(1,000$ cells per well in $100 \mu \mathrm{l})$. Cells were washed with PBS and lysed $(1 \times$ Cell Culture Lysis Reagent, Promega) 56-72 h after infection. Luciferase intensity was measured and the percentage of neutralization was calculated.

\section{Results}

DNA-S, MVA-S, and Ad5-S prime-boost immunizations in mice

To determine the $\mathrm{Nab}$ response to various prime-boost immunizations, we constructed separate DNA-S, MVA-S, and Ad5-S vaccines containing the full-length SARS-CoV $\mathrm{S}$ gene. We immunized three groups of BALB/c mice with either DNA-S (nine mice), MVA-S (six mice), or Ad5-S (six mice). Sera were collected 3 weeks after the first immunization, sequentially diluted (30- to 24,300-fold) and measured for the level of $\mathrm{Nab}$ activity against the SARSpseudovirus. As shown in Fig. 1, priming with Ad5-S elicited the highest level of Nabs against SARS-pseudovirus. MVA-S induces about tenfold $\left(\mathrm{IC}_{50}\right)$ lower levels of Nabs than Ad5-S, with DNA-S being the lowest (Fig. 1). Therefore, the live vector Ad5 may offer some advantages for inducing the highest level of Nab response after one immunization. Interestingly, this initial level of $\mathrm{Nab}$ after prime does not necessarily predict the magnitude of the secondary response after the boost.

Four weeks after the first immunization, the mice were boosted with DNA-S (D), MVA-S (M), or Ad5-S (A). Sera were collected 2 weeks after the boost, sequentially diluted (200- to 145,800-fold), and measured for the level of $\mathrm{Nab}$ activity against the SARS-pseudovirus. The second immunization has boosted the Nab response in all groups. When 


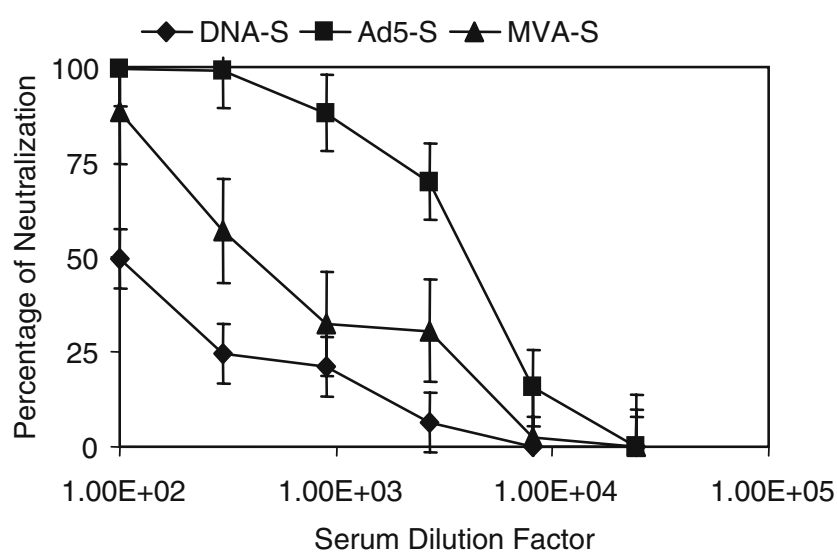

Fig. 1 Nab response in mice that were primed with DNA-S, MVA-S, or Ad5-S vaccines. Three mice as a group were tested for each vaccine. The average values of each test group and the standard error bars are presented. This neutralization experiment was repeated three times with consistent results obtained

we compared the regimen effects based on the $\mathrm{IC}_{50}$ and $\mathrm{IC}_{90}$ values, we found that a DNA-S prime, DNA-S boost (DD) regimen induced the lowest level of Nab activity (Fig. 2). On the other hand, priming with MVA-S and boosting with Ad5-S (MA) produced the highest level of Nabs, which is over tenfold greater than the DD animals (Fig. 2). We detected relatively lower levels of Nabs in mice primed with MVA-S or DNA-S and boosted with MVA-S (MM, DM) than MA animals (Fig. 2). Surprisingly, mice primed with Ad5-S and boosted with either Ad5-S or MVA-S (AA, AM) showed levels above the DD regimen, but below the rest (Fig. 2). This finding indicates the

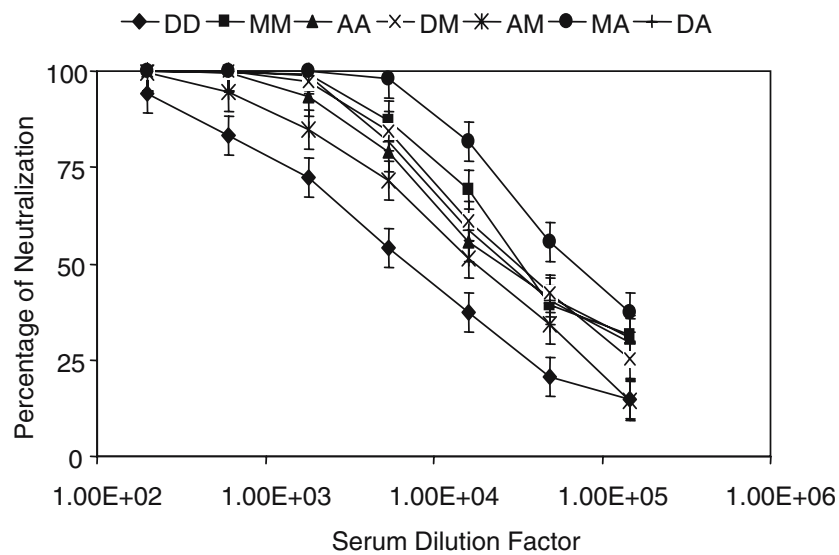

Fig. 2 Nab response in mice after the boost immunization with DNA-S, MVA-S, or Ad5-S vaccines. The letters present different combination of vaccinations: $D D$ for DNA-S prime and DNA-S boost; $M M$ for MVA-S prime and MVA-S boost; $A A$ for Ad5-S prime and Ad5-S boost; $D M$ for DNA-S prime and MVA-S boost; $A M$ for Ad5-S prime and MVA-S boost; $M A$ for MVA-S prime and AD5-S boost; and DA for DNA-S prime and AD5-S boost. Three mice as a group were tested for each vaccine. The average values of each test group and the standard error bars are presented. This neutralization experiment was repeated three times with consistent results obtained importance of heterologous MVA-S prime and Ad5-S boost regimen for inducing the substantial level of $\mathrm{Nab}$ response. The use of this regimen also offers an advantage to overcome the problems related to vaccine-induced immune response against these live viral vectors.

MVA-S and Ad5-S prime-boost immunizations in rabbits

To determine whether our findings in mice can be reproduced in a different animal species, we primed nine New Zealand white rabbits with either Ad5-S (six rabbits) or MVA-S (three rabbits). Thirty days after the first immunization, we measured the presence of Nabs to SARS in each rabbit serum. Collected serum was sequentially diluted 600- to 437,400-fold and analyzed for neutralizing activity against the SARS-pseudovirus. In the six rabbits immunized with Ad5-S, we measured an average $\mathrm{IC}_{50}$ of greater than a 54,000-fold serum dilution (Fig. 3). We observed a significantly greater level of Nabs (15-fold) in rabbits immunized with Ad5-S than in rabbits immunized with MVA-S, which showed an average $\mathrm{IC}_{50}$ of 3,600 (Fig. 3). Therefore, similar to mice, we showed that, after one immunization, we can induce a greater antibody response using Ad5-S, rather than MVA-S, as a viral vector vaccine.

After measuring the $\mathrm{Nab}$ response to priming, we boosted the rabbits with either Ad5-S or MVA-S. Three of the rabbits primed with Ad5-S were boosted with MVA-S (AM), whereas the remaining three were boosted with another injection of Ad5-S (AA). The three rabbits primed with MVA-S were boosted with Ad5-S (MA). Two weeks after the second injection, we collected the serum samples, sequentially diluted (1,800- to 1,312,200-fold) and measured it for the level of Nab activity against the SARSpseudovirus. Rabbits primed with Ad5-S and boosted with

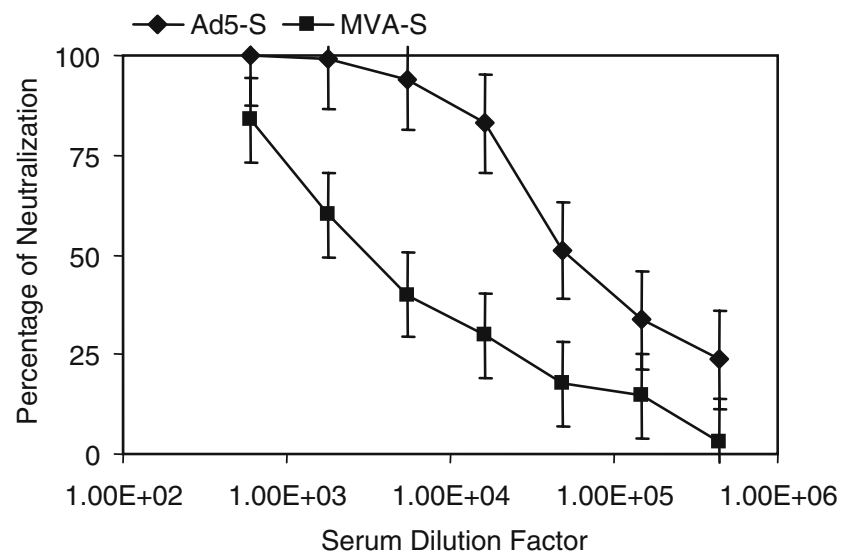

Fig. 3 Nab response in rabbits that were primed with MVA-S or Ad5-S vaccines. Three rabbits as a group were tested for each vaccine. The average values of each test group and the standard error bars are presented. This neutralization experiment was repeated three times with consistent results obtained 
either Ad5-S (AA) or MVA-S (AM) showed comparable levels of $\mathrm{Nab}$ activity (Fig. 4). However, in rabbits primed with MVA-S and boosted with Ad5-S (MA), we observed a significantly higher level of Nab activity compared with AM and AA rabbits (Fig. 4). MA rabbits had about five- to sevenfold higher $\mathrm{Nab}$ response in serum $\mathrm{Nab} \mathrm{IC}_{50}$ and $\mathrm{IC}_{90}$ after heterologous boosting than the AA animals. In comparison to the boost effects found in both $\mathrm{AM}$ and AA rabbits, heterologous boosting with Ad5-S likely determines the extent of the secondary $\mathrm{Nab}$ response in MA animals.

Prolonged Nab activity in rabbits with MVA-S prime and Ad5-S boost immunizations

Over a prolonged time course, we continued to observe a greater Nab response in rabbits primed with MVA-S and boosted with Ad5-S. In addition to the measurements 2 weeks after boosting, we measured the Nab response 6 , 9 , and 16 weeks after boosting. Based on $\mathrm{IC}_{50}$ extrapolations, we showed that the levels of $\mathrm{Nab}$ in MA rabbits remained significantly greater for as long as 4 months after the booster (Fig. 5). In fact, the $\mathrm{IC}_{50}$ levels that initially rose to a fourfold increase in MA rabbits over $\mathrm{AA}$ and $\mathrm{AM}$ rabbits 2 weeks after the boost remained two to three times greater over the extended measurements (Fig. 5). The same can be observed with $\mathrm{IC}_{90}$ serum Nab levels. $\mathrm{AM}$ rabbits only showed an average $\mathrm{IC}_{90}$ increase of twofold 14 days after the boost, with levels dropping back to what we observed upon Ad5-S priming (Fig. 5). AA rabbits failed to show an increase in $\mathrm{IC}_{90}$ serum $\mathrm{Nab}$ levels after the prime. MA rabbits, on the other hand, showed a five- to sevenfold

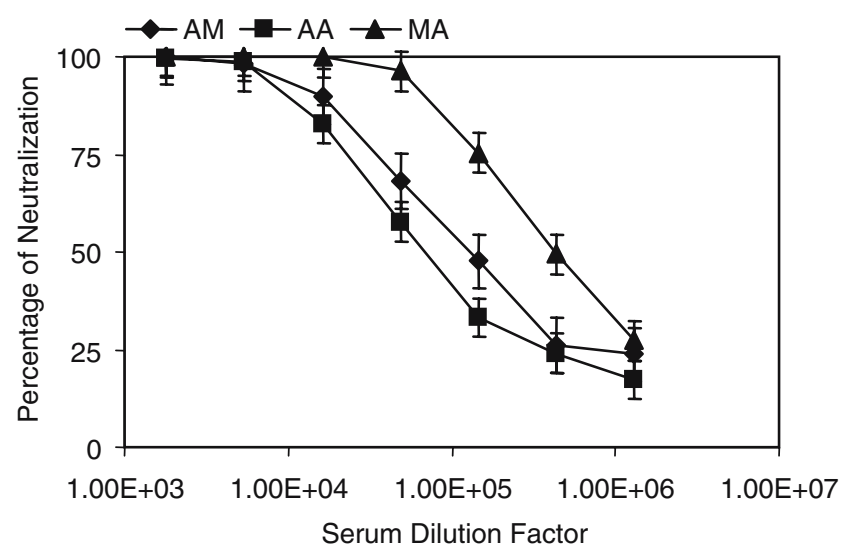

Fig. $4 \mathrm{Nab}$ response in rabbits after the boost immunization with MVA-S or Ad5-S vaccines. The letters present different combination of vaccinations: $A M$ for Ad5-S prime and MVA-S boost regimen; $A A$ for Ad5-S prime and Ad5-S boost regimen; and $M A$ for MVA-S prime and AD5-S boost regimen. Three rabbits as a group were tested for each regimen. The average values of each test group and the standard error bars are presented. This Nab experiment was repeated three times with consistent results obtained
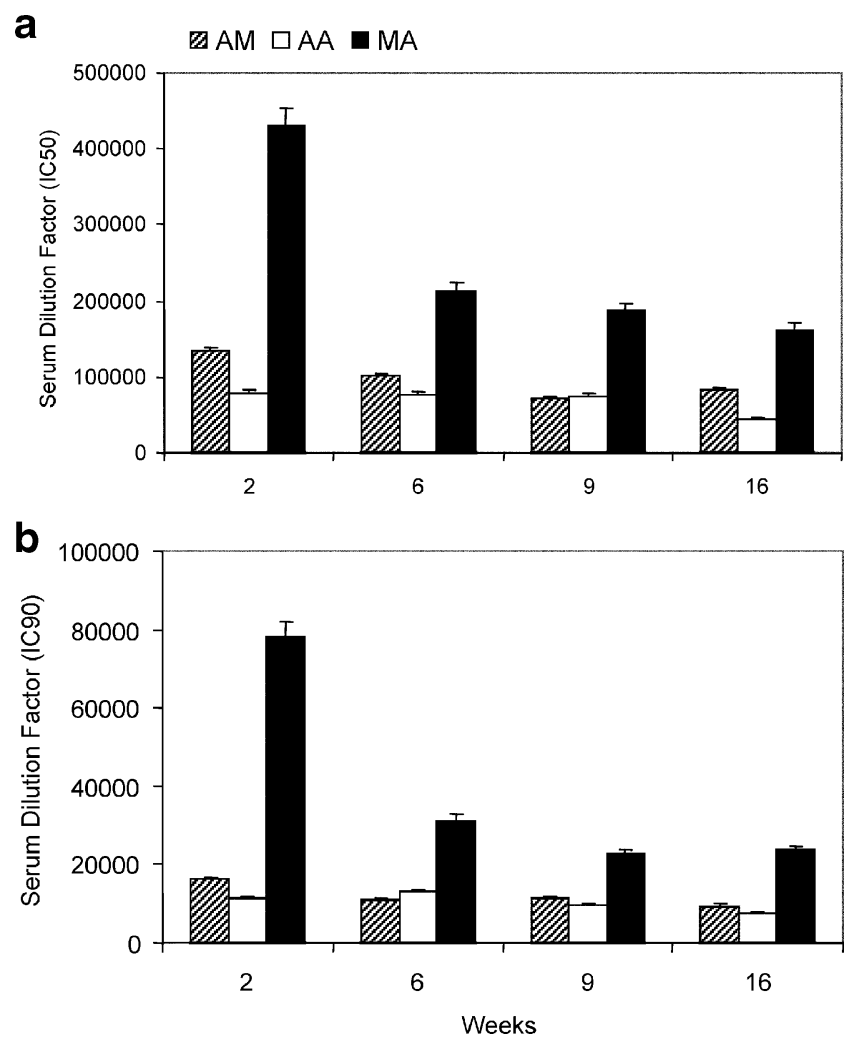

Fig. 5 Persistent Nab response after the boost immunization with MVA-S or Ad5-S vaccines in rabbits. The x-axis represents the time following boost immunization. The y-axis indicates the serum dilution titer when $\mathrm{IC}_{50}$ (a) or $\mathrm{IC}_{90}$ (b) was achieved. Three rabbits as a group were tested for each vaccine regimen. The average values of each test group and the standard error bars are presented. The neutralization assay was repeated three times with consistent results obtained

increase over $\mathrm{AM}$ and $\mathrm{AA}$ rabbit $\mathrm{IC}_{90} \mathrm{Nab}$ levels 2 weeks after the boost, with a sustained two- to threefold increase over 6, 9, and 16 weeks. Therefore, heterologous MVA-S prime and Ad5-S boost are shown to be the most immunogenic for eliciting a prolonged $\mathrm{Nab}$ immune response against SARS-CoV.

\section{Discussion}

With the emergence of the SARS epidemic in 2003, much attention has been focused on developing an effective vaccine to combat the threat of recurrence. Previously, we showed the promise of using the MVA-S to protect against a pathogenic SARS-CoV challenge in Chinese rhesus monkeys (Chen et al. 2005). Here, we studied various prime-boost regimens in both mice and rabbits to determine the optimal conditions required to induce the greatest, longlasting Nab response against SARS-CoV. Beginning with mice, priming with the nonreplication competent Ad5-S initiated the highest level of serum Nabs against the SARS$\mathrm{CoV}$ virus (Fig. 1). Both DNA-S and MVA-S priming 
showed significantly lower levels of Nabs induced. This primary $\mathrm{Nab}$ response, however, did not predict the effectiveness of the priming. Boosting the Ad5-S-primed mice with either MVA-S or Ad5-S resulted in an increase in serum Nabs. Interestingly, this increased level of $\mathrm{Nab}$ response was significantly lower than that of the MVA-Sprimed, Ad5-S-boosted mice (Fig. 2). This finding indicates the importance of heterologous MVA-S prime and Ad5-S boost regimen for inducing the substantial level of $\mathrm{Nab}$ response. The use of this regimen also offers an advantage to overcome the problems related to vaccine-induced immune response against these live viral vectors.

Similar to our findings in mice, we observed significantly lower levels of Nabs in rabbits primed with MVA-S, compared to Ad5-S (Fig. 3). Upon boosting Ad5-S-primed rabbits with either MVA-S or Ad5-S, the serum $\mathrm{IC}_{50} \mathrm{Nab}$ levels increased above twofold in Ad5-S-primed and MVAS-boosted animals and less than twofold for Ad5-S-primed and Ad5-S-boosted animals 2 weeks after boosting. However, MVA-S-primed and Ad5-S-boosted rabbits reached a significantly higher serum $\mathrm{Nab} \mathrm{IC}_{50}$ titer 2 weeks after boosting. We suspect that homologous Ad5-S (or MVA-S) prime and boost failed to reach substantial levels, because a preexisting immunity from the priming probably results in expedited vector interference or clearance. As for the heterologous vaccination regimen, the underlined mechanism for why priming with MVA-S is superior to Ad5-S is of interest for further investigation. It is possible that MVA-S is much better than Ad5-S for priming the memory B cells, which are essential for boosting the potent Nab response. Moreover, a high level of Nab response generated by Ad5-S priming does not necessarily indicate a similar level of memory response is simultaneously induced.

Over 16 weeks of observation, we found a significantly higher level (two- to threefold serum $\mathrm{IC}_{50}$ titer) of serum Nabs in MVA-S-primed and Ad5-S-boosted rabbits compared with animals that received other regimens. Furthermore, Nab measurements based on serum $\mathrm{IC}_{90}$ titer show an even more apparent disparity. The Ad5-S-primed and Ad5-S-boosted rabbits showed little beneficial effects with a homologous boost, whereas the Ad5-S-primed and MVAS-boosted rabbits showed a rapid twofold increase, with an $\mathrm{IC}_{90}$ returning to levels observed just after priming. MVAS-primed and Ad5-S-boosted rabbits, however, had a much greater $\mathrm{IC}_{90}$ increase after heterologous boosting, with persistently two- to threefold higher levels 16 weeks later. Clearly, rabbits primed with MVA-S and boosted with Ad5$\mathrm{S}$ show a substantial advantage over other immunization regimens tested in triggering a persistent vaccine-induced $\mathrm{Nab}$ response of high quality.

The quest to optimize vaccine vector delivery systems and prime-boost strategies is a subject often raised with HIV-1 vaccine design. Data generated in nonhuman primates has demonstrated that a DNA prime-MVA boost regimen was superior to either vaccines used alone for inducing high levels of protective cell-mediated response against pathogenic simian immunodeficiency virus (SIV) or human/simian immunodeficiency virus (SHIV; Amara et al. 2001; Horton et al. 2002). This strategy has also been proven to be effective against influenza and malaria (Degano et al. 1999; McConkey et al. 2003). Similarly, a DNA prime-Ad5 boost regimen also showed great efficacy in nonhuman primates against a SHIV challenge (Shiver et al. 2002). To date, a few studies have evaluated the regimens using live viral vectors. Among them, boosting of an adenovirus-primed immune response with a MVA vaccine led to enhanced immunogenicity and substantial protective efficacy in mice against malaria and SHIV infection (Casimiro et al. 2004; Gilbert et al. 2002). In fact, the MVA prime-adenovirus boost regimen scored second best in the study for inducing protective immunity (Gilbert et al. 2002). Here, we demonstrate for the first time that the heterologous MVA-S prime and Ad5-S boost regimen offers great advantages for inducing Nabs against SARS-CoV. This finding is useful to study AIDS vaccine design because it is recognized that the cell-mediated response alone is not sufficient to achieve sterile immunity against HIV-1. It is of great interest to determine whether this regimen would improve the immunogenicity profile of some promising, yet weak HIV-1 immunogens aimed at inducing Nabs.

Acknowledgements We thank the National Heart, Lung and Blood Institute (R01 HL080211-02 to Z.C.) and Aaron Diamond Fund for financial support. Lei $\mathrm{Ba}$ and Christopher $\mathrm{E}$. Yi made equal contributions.

\section{References}

Amara RR, Villinger F, Altman JD, Lydy SL, O’Neil SP, Staprans SI, Montefiori DC, Xu Y, Herndon JG, Wyatt LS, Candido MA, Kozyr NL, Earl PL, Smith JM, Ma HL, Grimm BD, Hulsey ML, Miller J, McClure HM, McNicholl JM, Moss B, Robinson HL (2001) Control of a mucosal challenge and prevention of AIDS by a multiprotein DNA/MVA vaccine. Science 292(5514):69-74

Bisht H, Roberts A, Vogel L, Bukreyev A, Collins PL, Murphy BR, Subbarao K, Moss B (2004) Severe acute respiratory syndrome coronavirus spike protein expressed by attenuated vaccinia virus protectively immunizes mice. Proc Natl Acad Sci U S A 101(17): 6641-6646

Bisht H, Roberts A, Vogel L, Subbarao K, Moss B (2005) Neutralizing antibody and protective immunity to SARS coronavirus infection of mice induced by a soluble recombinant polypeptide containing an $\mathrm{N}$-terminal segment of the spike glycoprotein. Virology 334(2):160-165

Bukreyev A, Lamirande EW, Buchholz UJ, Vogel LN, Elkins WR, St Claire M, Murphy BR, Subbarao K, Collins PL (2004) Mucosal immunisation of African green monkeys (Cercopithecus aethiops) with an attenuated parainfluenza virus expressing the SARS 
coronavirus spike protein for the prevention of SARS. Lancet 363 (9427):2122-2127

Casimiro DR, Bett AJ, Fu TM, Davies ME, Tang A, Wilson KA, Chen M, Long R, McKelvey T, Chastain M, Gurunathan S, Tartaglia J, Emini EA, Shiver J (2004) Heterologous human immunodeficiency virus type 1 priming-boosting immunization strategies involving replication-defective adenovirus and poxvirus vaccine vectors. J Virol 78(20):11434-11438

Chen Z, Zhang L, Qin C, Ba L, Yi CE, Zhang F, Wei Q, He T, Yu W, Yu J, Gao H, Tu X, Gettie A, Farzan M, Yuen KY, Ho DD (2005) Recombinant modified vaccinia virus Ankara expressing the spike glycoprotein of severe acute respiratory syndrome coronavirus induces protective neutralizing antibodies primarily targeting the receptor binding region. J Virol 79(5):2678-2688

Degano P, Schneider J, Hannan CM, Gilbert SC, Hill AV (1999) Gene gun intradermal DNA immunization followed by boosting with modified vaccinia virus Ankara: enhanced CD8+ T cell immunogenicity and protective efficacy in the influenza and malaria models. Vaccine 18(7-8):623-632

Deming D, Sheahan T, Heise M, Yount B, Davis N, Sims A, Suthar M, Harkema J, Whitmore A, Pickles R, West A, Donaldson E, Curtis K, Johnston R, Baric R (2006) Vaccine efficacy in senescent mice challenged with recombinant SARS-CoV bearing epidemic and zoonotic spike variants. PLoS Med 3(12):e525

Drosten C, Preiser W, Gunther S, Schmitz H, Doerr HW (2003) Severe acute respiratory syndrome: identification of the etiological agent. Trends Mol Med 9(8):325-327

Gao W, Tamin A, Soloff A, D'Aiuto L, Nwanegbo E, Robbins PD, Bellini WJ, Barratt-Boyes S, Gambotto A (2003) Effects of a SARSassociated coronavirus vaccine in monkeys. Lancet 362(9399): 1895-1896

Gilbert SC, Schneider J, Hannan CM, Hu JT, Plebanski M, Sinden R, Hill AV (2002) Enhanced CD8 T cell immunogenicity and protective efficacy in a mouse malaria model using a recombinant adenoviral vaccine in heterologous prime-boost immunisation regimes. Vaccine 20(7-8):1039-1045

He Y, Lu H, Siddiqui P, Zhou Y, Jiang S (2005) Receptor-binding domain of severe acute respiratory syndrome coronavirus spike protein contains multiple conformation-dependent epitopes that induce highly potent neutralizing antibodies. J Immunol 174(8): 4908-4915

Horton H, Vogel TU, Carter DK, Vielhuber K, Fuller DH, Shipley T, Fuller JT, Kunstman KJ, Sutter G, Montefiori DC, Erfle V, Desrosiers RC, Wilson N, Picker LJ, Wolinsky SM, Wang C, Allison DB, Watkins DI (2002) Immunization of rhesus macaques with a DNA prime/modified vaccinia virus Ankara boost regimen induces broad simian immunodeficiency virus (SIV)-specific T-cell responses and reduces initial viral replication but does not prevent disease progression following challenge with pathogenic SIVmac239. J Virol 76(14):7187-7202

Ksiazek TG, Erdman D, Goldsmith CS, Zaki SR, Peret T, Emery S, Tong S, Urbani C, Comer JA, Lim W, Rollin PE, Dowell SF, Ling AE, Humphrey CD, Shieh WJ, Guarner J, Paddock CD, Rota P, Fields B, DeRisi J, Yang JY, Cox N, Hughes JM, LeDuc JW, Bellini WJ, Anderson LJ (2003) A novel coronavirus associated with severe acute respiratory syndrome. N Engl J Med 348(20):1953-1966

Kuiken T, Fouchier RA, Schutten M, Rimmelzwaan GF, van Amerongen $\mathrm{G}$, van Riel D, Laman JD, de Jong T, van Doornum G, Lim W, Ling AE, Chan PK, Tam JS, Zambon MC, Gopal R,
Drosten C, van der Werf S, Escriou N, Manuguerra JC, Stohr K, Peiris JS, Osterhaus AD (2003) Newly discovered coronavirus as the primary cause of severe acute respiratory syndrome. Lancet 362(9380):263-270

Li, W., Moore, M.J., Vasilieva, N., Sui, J., Wong, S.K., Berne, M.A., Somasundaran, M., Sullivan, J.L., Luzuriaga, K., Greenough, T. C., Choe, H., Farzan, M (2003) Angiotensin-converting enzyme 2 is a functional receptor for the SARS coronavirus. Nature 426 (6965), 450-454

Li F, Li W, Farzan M, Harrison SC (2005) Structure of SARS coronavirus spike receptor-binding domain complexed with receptor. Science 309(5742):1864-1868

Liu L, Fang Q, Deng F, Wang H, Yi CE, Ba L, Yu W, Lin RD, Li T, Hu Z, Ho DD, Zhang L, Chen Z (2007) Natural mutations in the receptor binding domain of spike glycoprotein determine the reactivity of cross-neutralization between palm civet coronavirus and severe acute respiratory syndrome coronavirus. J Virol 81(9): 4694-4700

McConkey SJ, Reece WH, Moorthy VS, Webster D, Dunachie S, Butcher G, Vuola JM, Blanchard TJ, Gothard P, Watkins K, Hannan CM, Everaere S, Brown K, Kester KE, Cummings J, Williams J, Heppner DG, Pathan A, Flanagan K, Arulanantham N, Roberts MT, Roy M, Smith GL, Schneider J, Peto T, Sinden RE, Gilbert SC, Hill AV (2003) Enhanced T-cell immunogenicity of plasmid DNA vaccines boosted by recombinant modified vaccinia virus Ankara in humans. Nat Med 9(6):729-735

Peiris JS, Lai ST, Poon LL, Guan Y, Yam LY, Lim W, Nicholls J, Yee WK, Yan WW, Cheung MT, Cheng VC, Chan KH, Tsang DN, Yung RW, Ng TK, Yuen KY (2003) Coronavirus as a possible cause of severe acute respiratory syndrome. Lancet 361(9366):1319-1325

Shiver JW, Fu TM, Chen L, Casimiro DR, Davies ME, Evans RK, Zhang ZQ, Simon AJ, Trigona WL, Dubey SA, Huang L, Harris VA, Long RS, Liang X, Handt L, Schleif WA, Zhu L, Freed DC, Persaud NV, Guan L, Punt KS, Tang A, Chen M, Wilson KA, Collins KB, Heidecker GJ, Fernandez VR, Perry HC, Joyce JG, Grimm KM, Cook JC, Keller PM, Kresock DS, Mach H, Troutman RD, Isopi LA, Williams DM, Xu Z, Bohannon KE, Volkin DB, Montefiori DC, Miura A, Krivulka GR, Lifton MA, Kuroda MJ, Schmitz JE, Letvin NL, Caulfield MJ, Bett AJ, Youil R, Kaslow DC, Emini EA (2002) Replication-incompetent adenoviral vaccine vector elicits effective anti-immunodeficiencyvirus immunity. Nature 415(6869):331-335

Yang ZY, Kong WP, Huang Y, Roberts A, Murphy BR, Subbarao K, Nabel GJ (2004) A DNA vaccine induces SARS coronavirus neutralization and protective immunity in mice. Nature 428(6982): $561-564$

Yi CE, Ba L, Zhang L, Ho DD, Chen Z (2005) Single amino acid substitutions in the severe acute respiratory syndrome coronavirus spike glycoprotein determine viral entry and immunogenicity of a major neutralizing domain. J Virol 79(18):11638-11646

Zeng FY, Chan CW, Chan MN, Chen JD, Chow KY, Hon CC, Hui KH, Li J, Li VY, Wang CY, Wang PY, Guan Y, Zheng B, Poon LL, Chan KH, Yuen KY, Peiris JS, Leung FC (2003) The complete genome sequence of severe acute respiratory syndrome coronavirus strain HKU-39849 (HK-39). Exp Biol Med (Maywood) 228(7):866-873

Zhang L, Zhang F, Yu W, He T, Yu J, Yi CE, Ba L, Li W, Farzan M, Chen Z, Yuen KY, Ho D (2006) Antibody responses against SARS coronavirus are correlated with disease outcome of infected individuals. J Med Virol 78(1):1-8 